\title{
EFFECTS OF SOIL WATER AVAILABILITY AND ORGANIC MATTER CONTENT ON FRUIT YIELD AND SEED OIL CONTENT OF CASTOR BEAN ${ }^{1}$
}

\author{
Rogério D. de Lacerda ${ }^{2 *}$, Larissa C. Almeida ${ }^{3}$, \\ Hugo O. C. Guerra ${ }^{4}$, José E. B. da Silva ${ }^{4}$
}

${ }^{2 *}$ IFRN - Instituto Federal de Educação, Ciência e Tecnologia do Rio Grande do Norte/Apodi - RN, Brasil.

E-mail: rogerio_dl@yahoo.com.br | ORCID ID: http://orcid.org/0000-0002-8079-2655

\section{KEYWORDS}

"BRS 188

Paraguaçu," Ricinus

communis L.,

irrigation, biodiesel.

\begin{abstract}
The objective of this study was to assess the sensitivity of the castor bean cultivar "BRS 188 Paraguaçu" to available soil water for plants and soil organic matter content based on their effects on fruit yield and seed oil content. A $2 \times 4$ factorial experiment was conducted from October 2008 to March 2009 under field conditions using randomized complete block design; two soil organic matter contents $\left(5.0\right.$ and $\left.25.0 \mathrm{~g} \cdot \mathrm{kg}^{-1}\right)$ and four available soil water levels for plants at the irrigation time $(70,80,90$, and $100 \%$ of the total available soil water) with three replicates were tested. On each experimental unit measuring $100 \mathrm{~m}^{2}, 50$ plants were cultivated with a spacing of $2 \mathrm{~m} \times 1 \mathrm{~m}$ (24 useful and 26 border plants). Analysis of variance ( $\mathrm{F}$ test) was performed; qualitative factors (soil organic matter) were compared by Tukey's test and quantitative factors (available soil water) by regression analysis. Increased soil organic matter and available soil water for plants substantially increased productivity; however, seed oil content, mean 100-seed mass, mean 100-fruit mass, and seed:fruit ratio were affected by available soil water content alone. Therefore, the tested cultivar is sensitive to reduced available soil water content, which severely decreases its productivity.
\end{abstract}

\section{INTRODUCTION}

Castor bean (Ricinus communis L.) is an oilseed crop of outstanding social and economic importance in Brazil and the world. Castor oil is used as a raw material for unique applications in the chemical industry due to the peculiar characteristics of its molecule, which make it the only naturally hydroxylated vegetable oil, as well as due to the composition predominantly containing a single ricinoleic fatty acid, which gives it atypical chemical properties (Azevedo \& Beltrão, 2007). Castor bean is an euphorbiaceous crop traditionally grown by small producers but commercially exploited due to the high oil content of its seeds. Brazil is one of the three largest producers of castor beans in the world, alternating throughout the history with China and India (Rodrigues et al., 2010).

In Northeast Brazil, agriculture plays an important role in the regional economy. However, climate adversities combined with outdated agricultural practices make it basically a subsistence activity. Considering that irrigated agriculture is a great alternative for this region, the available water resources must be used rationally, necessitating the proper use of water, soil, and crop management techniques (Freitas et al., 2010).

Barros Júnior et al. (2008) demonstrated that reduced soil water content significantly affects the height and diameter of castor bean stem, with a reduction of 40 to $60 \%$ of available water resulting in the blockade of plant development. When field capacity associated with adequate management is maintained, concomitantly with the use of other necessary inputs for adequate crop development, castor bean presents a high productive potential, efficiently transforming inputs into dry matter production and, consequently, in fruit production per unit cultivated area.

Castor bean requires water at the early stages of growth and in a dry season at the stages of fruit ripening and drying. Considering that crop in the field, mainly in

\footnotetext{
${ }^{1}$ Part of the first author Doctorate degree thesis.

${ }^{3}$ UFRPE/ Recife - PE, Brasil.

${ }^{4}$ UFCG/ Campina Grande - PB, Brasil.

Area Editor: Rogério Teixeira de Faria

Received in: 4-22-2011

Accepted in: 9-21-2020
} 
Northeast Brazil, is exposed to water deficit, water supplementation through irrigation at times of the greatest crop water demand improves productive performance (Diniz Neto et al., 2009). Water deficit differently affects plant development, stomatal opening, photosynthesis, and growth (Medici et al., 2007), depending on plant genotype and water deficit intensity.

Soil organic matter content is one of the main conditioning factors for crop yield and soil ecosystem functioning. The rate of organic matter decomposition depends to some extent on cultivation practices, mainly those related to soil system and incorporation of crop residues. According to Sampaio \& Salcedo (1997), soil organic matter in semi-arid regions decreases due to nutrient removal by crops, erosion, leaching, and burning of crop residues at the time of harvest. Humic substances, the major components of soil organic matter, have been studied in several areas of agriculture due to their important functions, which may improve crop production. These substances are involved in agronomic, environmental, and geochemical processes and serve as a reservoir of soil micronutrients, which are later made available to plants (Maccarthy, 2001).

However, use of irrigation in agriculture increases production costs; thus, to justify its use, high yield must be obtained. This has necessitated the use of cultivars that best respond to water availability and the most appropriate water management approaches, which can increase yield while lowering costs in a sustainable way (Souza et al., 2007).

To this end, the objective of this study was to analyze the sensitivity of the castor bean cultivar "BRS 188 Paraguaçu" to different levels of soil water availability and organic matter content based on their effects on productivity and seed oil content, aimed at meeting the growing demands of Brazilian agribusiness.

\section{MATERIAL AND METHODS}

The study was conducted between October 2008 and April 2009 in an experimental area of the State University of Paraíba, in the municipality of Lagoa Seca, PB, Brazil $\left(7^{\circ} 15^{\prime} \mathrm{S} 35^{\circ} 2^{\prime} \mathrm{W}, 634 \mathrm{~m}\right.$ altitude). Average annual ambient temperature is 18 to $33^{\circ} \mathrm{C}$, and average annual relative humidity is approximately $80 \%$. The predominant soil in the study area is Euthrophic Regolitical Neosol of the loamyclayey-sandy texture and with low organic matter content. Soil hydrophysical characteristics are summarized in Table 1.

TABLE 1. Hydrophysical characteristics of soil $(0-20 \mathrm{~cm})$.

\begin{tabular}{lc}
\hline Characteristics & Values \\
\hline Clay $\left(\mathrm{g} \cdot \mathrm{kg}^{-1}\right)$ & 277.6 \\
Silt $\left(\mathrm{g} \cdot \mathrm{kg}^{-1}\right)$ & 87.2 \\
Sand $\left(\mathrm{g} \cdot \mathrm{kg}^{-1}\right)$ & 635.2 \\
Texture classification* & Loamy-clayey-sandy \\
Density $\left(\mathrm{kg} \cdot \mathrm{m}^{-3}\right)$ & $1,380.0$ \\
Particle density $\left(\mathrm{kg} \cdot \mathrm{m}^{-3}\right)$ & $2,650.0$ \\
Porosity $\left(\mathrm{m}^{3} \cdot \mathrm{m}^{-3}\right)$ & 0.4792 \\
Capacity field $\left(\mathrm{m}^{3} \cdot \mathrm{m}^{-3}\right)$ & 0.1990 \\
Withering point $\left(\mathrm{m}^{3} \cdot \mathrm{m}^{-3}\right)$ & 0.0558 \\
Water available for plants $\left(\mathrm{m}^{3} \cdot \mathrm{m}^{-3}\right)$ & 0.1432 \\
Organic matter $\left(\mathrm{g} \cdot \mathrm{kg}^{-1}\right)$ & 5 \\
\hline
\end{tabular}

*Classification according to the United States Department of Agriculture.
A $2 \times 4$ factorial experiment with randomized complete block design, comprising two levels of soil organic matter and four levels of available soil water, was performed in three replicates. The evaluated treatments included two soil organic matter contents [5 (residual) and $25 \mathrm{~g} \cdot \mathrm{kg}^{-1}$ (incorporated)] and four available soil water levels $(70,80,90$, and $100 \%$ of total available water).

At the end of the experiment at 180 days after sowing (DAS), mean fruit yield, mean 100-fruit mass, mean 100seed mass, seed:fruit ratio, and seed oil content were statistically tested using analysis of variance (ANOVA), Tukey's test for the comparison of means between treatments, and regression analysis of available soil water level, as described by Ferreira (2000).

Mean fruit yield $\left(\mathrm{kg} \cdot \mathrm{ha}^{-1}\right)$ was obtained by dividing the yield of each unit treatment by unit area (ha). To calculate mean 100-fruit mass, mean 100-seed mass, and seed:fruit ratio, fruit were collected from each treatment, air dried, counted, weighed, and opened and seeds were weighed on a precision scale. Seed oil content was determined by nuclear magnetic resonance technique with an Oxford 4000 continuous wave spectrometer for quantitative analysis at a radio current emission frequency of $250 \mathrm{~mA}$ for a sample volume of $40 \mathrm{~cm}^{3}$ and an integration time of $20 \mathrm{~s}$.

Combinations of soil organic matter content and available soil water level at the time of irrigation resulted in eight treatments arranged in three blocks. Thus, the experiment had 24 plots with a usable area of $100 \mathrm{~m}^{2}$. In each plot, 50 plants were cultivated ( 24 useful plants and 26 border plants, spaced at $2.0 \mathrm{~m} \times 1.0 \mathrm{~m}$ ), totaling 1,200 plants in the experiment. The experiment was conducted over a 180-day cycle.

The treatment of $5 \mathrm{~g} \cdot \mathrm{kg}^{-1}$ organic matter corresponded to the organic matter present in the soil of the experimental area and predominant in that region (Table 1). The treatment of $25 \mathrm{~g} \cdot \mathrm{kg}^{-1}$ organic matter corresponded to the mean value of most soils in the semi-arid regions of Brazil, which was obtained by adding $42 \mathrm{~kg}$ of tanned cattle manure for each plant with $23.23 \%$ organic matter and $51.0 \%$ humidity on a dry matter basis at $65^{\circ} \mathrm{C}$.

Irrigation blades used were the same as those described previously in preliminary greenhouse studies of the same castor bean cultivar (Barros Júnior, 2007; Lacerda et al., 2009). Plants were cultivated in contour lines with a sowing depth of 2 to $3 \mathrm{~cm}$, and four seeds were sown in each hole. The plants were irrigated using a drip system with a single lateral line of drippers per plant row, spaced $2.0 \mathrm{~m}$ apart, and emitters, providing a continuous wetland strip with a width of $0.6 \mathrm{~m}$ per plant row; the flow rate was 1.5 $\mathrm{L} \cdot \mathrm{h}^{-1}$. Each treatments had an independent irrigation system. Application times were different, depending on the irrigation blades used in the treatment.

Irrigation was performed when soil water content reached the preset values for each treatment $(70,80,90$, and $100 \%$ of total available water); soil water content was monitored every 2 days using an HH2 PR1/6 segmented TDR probe (DELTA-T DEVICES) calibrated to the soil in the experimental area and inserted through an access tube installed in each plot up to a depth of $40 \mathrm{~cm}$.

Available soil water level was calculated using the equation described previously (Bernardo et al., 2008), as follows: 


$$
\mathrm{TAW}=\left(\frac{\mathrm{FC}-\mathrm{PWP}}{100}\right) \mathrm{d} \mathrm{Z}
$$

Where:

TAW - total available water in soil, $\mathrm{mm}$;

FC - soil water content at the field capacity, dry weight basis;

PWP - soil water content at a permanent withering point, dry weight basis;

d - apparent soil density, adimensional,

$\mathrm{Z}$ - effective castor bean root depth, $400 \mathrm{~mm}$.

Soil FC and PWP were determined using a Richard's extractor according to the methodology recommended by EMBRAPA (1997).

Raw irrigation blade (RB; equation 2) applied as a function of each treatment was calculated based on the quotient of liquid irrigation blade (IB; equation 3) and the efficiency of the irrigation system (E, decimal), which is 95\% for drip irrigation (0.95), as follows:

$$
\mathrm{RB}=\left(\frac{\mathrm{IB}}{\mathrm{E}}\right)
$$

Where:

IB - irrigation blade, $\mathrm{mm}$,

E - irrigation system efficiency, decimal.

$$
\mathrm{IB}=\mathrm{TAW}\left(\frac{100-\% \mathrm{TAW}}{100}\right)
$$

Where:
IB - liquid irrigation blade, $\mathrm{mm}$,

\% TAW - percentage of total available water in the soil at the time of irrigation for each treatment.

Thinning was conducted at 20 DAS, leaving only two vigorous plants per hole, and at 30 DAS, leaving one plant per hole.

Soil was fertilized with triple superphosphate on foundation at $120 \mathrm{~kg} \cdot \mathrm{ha}^{-1} \mathrm{P}_{2} \mathrm{O}_{5}$ and on cover at $100 \mathrm{~kg} \cdot \mathrm{ha}^{-1}$ $\mathrm{K}_{2} \mathrm{O}$. Nitrogen was supplied in the form of potassium chloride and urea, divided into 10-day intervals applied via fertigation, with the first application at 20 DAS.

The cultivar tested was "BRS 188 Paraguaçu," which has a medium height of $1.60 \mathrm{~m}$, purple stem with wax, oval raceme, semi-dehiscent fruit, and black seeds. The mean period between seedling emergence and flowering of the first raceme is 54 days, mean 100-seed mass is $71.0 \mathrm{~g}$, mean seed oil content is $47.72 \%$, and mean yield without fertilization is $1,500 \mathrm{~kg} \cdot \mathrm{ha}^{-1}$ under semi-arid conditions in normal years with 750-mm rainfall (Azevedo \& Beltrão, 2007).

\section{RESULTS AND DISCUSSION}

\section{Mean fruit yield}

The results of ANOVA for fruit yield are shown in Table 2. Mean fruit yield of "BRS 188 Paraguaçu" was significantly affected $(p<0.05)$ by the organic matter contents tested, and the mean fruit yield of plants grown in soil with $25 \mathrm{~g} \cdot \mathrm{kg}^{-1}$ organic matter was higher $(17.38 \%)$ than that of plants grown in soil with $5 \mathrm{~g} \cdot \mathrm{kg}^{-1}$ organic matter. In a study by Bayer \& Mielniczuk (2008), low organic matter content of tropical and subtropical soils was the key factor

\begin{tabular}{|c|c|c|c|}
\hline Source of variation & DF & \multicolumn{2}{|c|}{ Mean square } \\
\hline Organic matter $(\mathrm{OM})$ & 1 & \multicolumn{2}{|c|}{$3523472.95^{*}$} \\
\hline Available water (AW) & 3 & \multicolumn{2}{|c|}{$6725698.79 * *$} \\
\hline $\mathrm{AW} \times \mathrm{OM}$ interaction & 3 & \multicolumn{2}{|c|}{$348336.47^{\mathrm{ns}}$} \\
\hline Blocks & 2 & \multicolumn{2}{|c|}{$93106.01^{\mathrm{ns}}$} \\
\hline$\underline{\text { Residue }}$ & 14 & \multicolumn{2}{|c|}{603282.92} \\
\hline CV\% & & \multicolumn{2}{|c|}{18.18} \\
\hline Available water & & $\mathrm{OM}\left(5 \mathrm{~g} \cdot \mathrm{kg}^{-1}\right)$ & $\mathrm{OM}\left(25 \mathrm{~g} \cdot \mathrm{kg}^{-1}\right)$ \\
\hline Linear Pol. Reg. & & $7117026.00 * *$ & $13135075.97 * *$ \\
\hline Quadratic Pol. Reg. & & $42566.34^{\mathrm{ns}}$ & $749000.33^{\text {ns }}$ \\
\hline Cubic Pol. Reg. & & $136374.33^{\mathrm{ns}}$ & $42315.39^{\mathrm{ns}}$ \\
\hline Deviation & & $0.00^{\mathrm{ns}}$ & $0.00^{\mathrm{ns}}$ \\
\hline Residue & & 599133.88 & 788785.30 \\
\hline $\mathrm{OM}$ & & \multicolumn{2}{|c|}{ Fruit yield $\left(\mathrm{kg} \cdot \mathrm{ha}^{-1}\right)$} \\
\hline $5 \mathrm{~g} \cdot \mathrm{kg}^{-1}$ & & \multicolumn{2}{|c|}{$3889.75^{\mathrm{b}}$} \\
\hline $25 \mathrm{~g} \cdot \mathrm{kg}^{-1}$ & & \multicolumn{2}{|c|}{$4656.07^{\mathrm{a}}$} \\
\hline MSD & & \multicolumn{2}{|c|}{680.09} \\
\hline
\end{tabular}
responsible for low crop yield as a result of limited $\mathrm{N}$ supply.

TABLE 2. Results of ANOVA for mean fruit yield of the "BRS 188 Paraguaçu” cultivar.

$\mathrm{DF}$, degree of freedom; CV, coefficient of variation; MSD, minimum significant difference; Significant at $0.05(*)$ and $0.01(* *)$ probability; $\left.{ }^{(n s}\right)$ not significant; means followed by the same letter in a column are not significantly different $(\mathrm{p}>0.05)$. 
Available water level in the soil at the time of irrigation significantly affected $(\mathrm{p}<0.01)$ mean fruit yield of the castor bean cultivar tested. Notably, plants whose soil was maintained at the field capacity $(100 \%$ available water $)$ showed mean fruit yield of $4,911.11 \mathrm{~kg} \cdot \mathrm{ha}^{-1}$ when grown in soil with $5 \mathrm{~g} \cdot \mathrm{kg}^{-1}$ organic matter and $6,336.11 \mathrm{~kg} \cdot \mathrm{ha}^{-1}$ when grown in soil with $25 \mathrm{~g} \cdot \mathrm{kg}^{-1}$ organic matter.
Regression analysis showed a significantly increasing linear trend for yield with increasing available water level in the soil at the time of irrigation (Figure 1). With $1 \%$ increase in available water level in the soil, fruit yield increased by $91.48 \mathrm{~kg} \cdot \mathrm{ha}^{-1}$ when grown in soil with 25 $\mathrm{g} \cdot \mathrm{kg}^{-1}$ and by $68.88 \mathrm{~kg} \cdot \mathrm{ha}^{-1}$ when grown in soil with $5 \mathrm{~g} \cdot \mathrm{kg}^{-}$ ${ }^{1}$ organic matter.

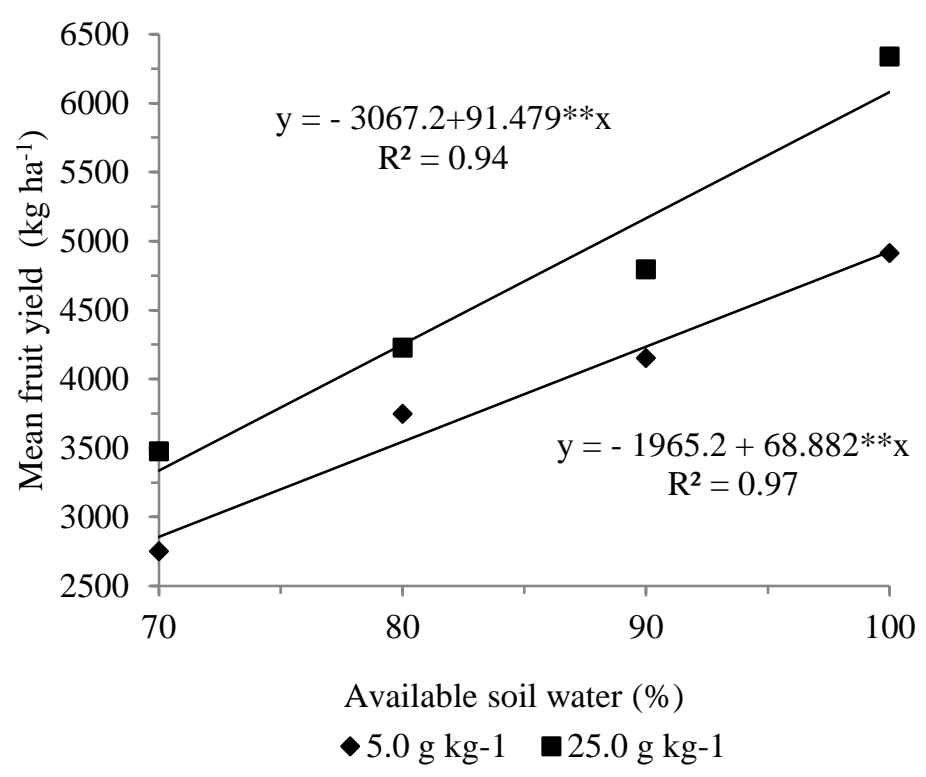

FIGURE 1. Mean fruit yield of the "BRS 188 Paraguaçu" cultivar as a function of soil organic matter content and available water level. Mean fruit yield was affected by soil organic matter content and available water level.

In the castor bean cultivar "Pronto," Koutroubas et al. (2000) detected reductions in productivity of 10.5 and $15.8 \%$ by reducing the irrigation blades to 0.75 and 0.50 of the maximum evapotranspiration of the crop, respectively. Meanwhile, Laureti (2002) reported a decrease of $8.7 \%$ in the production of castor bean hybrid ISCIOR 101 by reducing the irrigation blade.

In a greenhouse experiment over 180 DAS, Barros Júnior et al. (2008) observed that the "Paraguaçu" cultivar presented high sensitivity to available soil water; as such, plants cultivated in soil with $8 \%$ available water showed 83.9 and $83.4 \%$ reductions in fruit and seed yields, respectively, compared with plants cultivated in soil with $100 \%$ available water.

Similarly, Barros Júnior et al. (2008) found that 40 to $60 \%$ available water delayed castor bean development. According to Sausen \& Rosa (2010), water deficit alters carbohydrate partitioning in plants, conditioning them to adapt to and resist delayed growth. Therefore, plant tolerance to water deficit may be an important resistance mechanism for maintaining plant yield under water scarcity.
Fruit yield of plants cultivated in soil with $100 \%$ available water and $25 \mathrm{~g} \mathrm{~kg}^{-1}$ organic matter $(6,336.11$ $\left.\mathrm{kg} \cdot \mathrm{ha}^{-1}\right)$ was greater than the value reported by de Gondim et al. (2004) in experiments using genotypes imported from Costa Rica to the State of Ceará, which were irrigated by sprinkling $\left(3,494.0 \mathrm{~kg} \cdot \mathrm{ha}^{-1}\right.$ for genotype CSRN-142). The yield obtained in the present study also exceeded that obtained by Curi \& Campelo Júnior (2004) for an irrigated Iris cultivar $\left(2,345.5 \mathrm{~kg} \cdot \mathrm{ha}^{-1}\right)$ as well as that obtained by Carvalho (2005) for "Nordestina" and "Paraguaçu" $\left(5,400.0 \mathrm{~kg} \cdot \mathrm{ha}^{-1}\right)$.

Mean 100-fruit mass, mean 100-seed mass, and seed:fruit ratio

There was no significant effect of soil organic matter content on mean 100-fruit mass (Table 3); however, available water level in the soil significantly affected ( $\mathrm{p}<$ 0.05) mean 100-fruit mass. Mean 100-fruit mass of plants cultivated in soil maintained at the field capacity $(100 \%$ available water) increased by $7.6,14.3$, and $16.7 \%$ compared with plants cultivated in soil with 90,80 , and $70 \%$ available water, respectively. 
TABLE 3. Results of ANOVA for mean 100-fruit mass (M100F), mean 100-seed mass (M100S), and seed:fruit ratio up to 180 days after sowing of the "BRS 188 Paraguaçu" cultivar.

\begin{tabular}{|c|c|c|c|c|}
\hline \multirow{2}{*}{ Source of variation } & \multirow{2}{*}{$\mathrm{DF}$} & \multicolumn{3}{|c|}{ Mean square } \\
\hline & & $\mathrm{M} 100 \mathrm{~F}(\mathrm{~g})$ & M100S (g) & Seed:fruit ratio $\left(\mathrm{g}^{-1}\right)$ \\
\hline Organic matter (OM) & 1 & $28.17^{\mathrm{ns}}$ & $3.09^{\mathrm{ns}}$ & $0.000495^{\mathrm{ns}}$ \\
\hline Available water (AW) & 3 & $3828.06^{*}$ & $77.41^{*}$ & $0.006957^{*}$ \\
\hline $\mathrm{OM} \times \mathrm{AW}$ interaction & 3 & $20.11^{\mathrm{ns}}$ & $3.04^{\mathrm{ns}}$ & $0.000076^{\mathrm{ns}}$ \\
\hline Blocks & 2 & $1077.45^{\mathrm{ns}}$ & $7.67^{\mathrm{ns}}$ & $0.000587^{\mathrm{ns}}$ \\
\hline Residue & 14 & 1178.41 & 31.50 & 0.001899 \\
\hline CV\% & & 9.54 & 7.39 & 6.57 \\
\hline \multicolumn{5}{|l|}{ Available water } \\
\hline Linear Pol. Reg. & & $10807.97 * *$ & $210.09 *$ & $0.01938 * *$ \\
\hline Quadratic Pol. Reg. & & $658.35 \mathrm{~ns}$ & $0.76^{\mathrm{ns}}$ & $0.00148^{\mathrm{ns}}$ \\
\hline Cubic Pol. Reg. & & $17.07 \mathrm{~ns}$ & $21.38^{\mathrm{ns}}$ & $0.000002^{\mathrm{ns}}$ \\
\hline Deviation & & $0.00^{\mathrm{ns}}$ & $0.00^{\mathrm{ns}}$ & $0.0000^{\mathrm{ns}}$ \\
\hline Residue & & 1178.41 & 31.50 & 0.00189 \\
\hline \multicolumn{5}{|l|}{$\mathrm{OM}$} \\
\hline$\overline{5 \mathrm{~g} \cdot \mathrm{kg}^{-1}}$ & & $358.90^{\mathrm{a}}$ & $75.60^{\mathrm{a}}$ & $0.658^{\mathrm{a}}$ \\
\hline $25 \mathrm{~g} \cdot \mathrm{kg}^{-1}$ & & $361.08^{\mathrm{a}}$ & $76.32^{\mathrm{a}}$ & $0.668^{\mathrm{a}}$ \\
\hline MSD & & 30.05 & 4.91 & 0.038 \\
\hline
\end{tabular}

DF, degree of freedom; CV, coefficient of variation; MSD, minimum significant difference; Significant at $0.05(*)$ and $0.01(* *)$ probability;

$\left({ }^{\text {ns }) ~ n o t ~ s i g n i f i c a n t ; ~ m e a n s ~ f o l l o w e d ~ b y ~ t h e ~ s a m e ~ l e t t e r ~ i n ~ a ~ c o l u m n ~ a r e ~ n o t ~ s i g n i f i c a n t l y ~ d i f f e r e n t ~(~} p>0.05\right)$.

Mean 100-fruit mass of the tested cultivar presented a linear increasing trend with increase in available water level in the soil; as such, mean 100-fruit mass increased by $1.90 \mathrm{~g}$ with $1 \%$ increase in available soil water level (Figure 2).

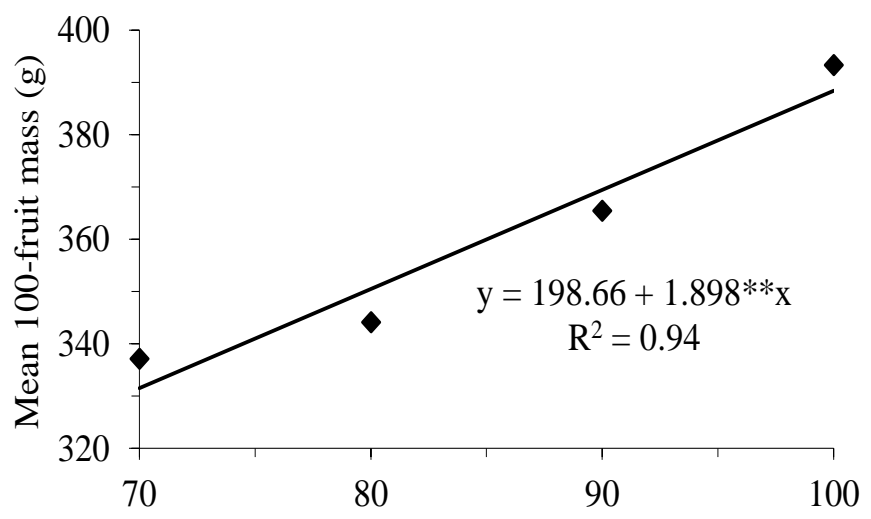

Available soil water $(\%)$

FIGURE 2. Mean 100-fruit mass of the "BRS 188 Paraguaçu" cultivar as a function of available soil water level

Available water in the soil significantly affected ( $p<$ 0.05 ) mean 100-seed mass (Table 3). Mean 100-seed masses obtained from plants cultivated in soil with 100, 90, 80 , and $70 \%$ available water were $80.54,75.84,75.73$, and $71.75 \mathrm{~g}$, respectively; these values are higher than those obtained by Azevedo \& Beltrão (2007) (71 g) and Carvalho (2005) (63.2 g) for the "Paraguaçu" cultivar. Under similar greenhouse conditions, Barros Júnior et al. (2008) obtained a mass of $67.3 \mathrm{~g}$ for the "Paraguaçu" cultivar grown in the absence of water stress; however, in soil with $80 \%$ available water, mean mass decreased to $56.7 \mathrm{~g}$.

Mean 100-seed mass increased by $0.26 \mathrm{~g}$ with $1 \%$ increase in available water level in the soil (Figure 3). 


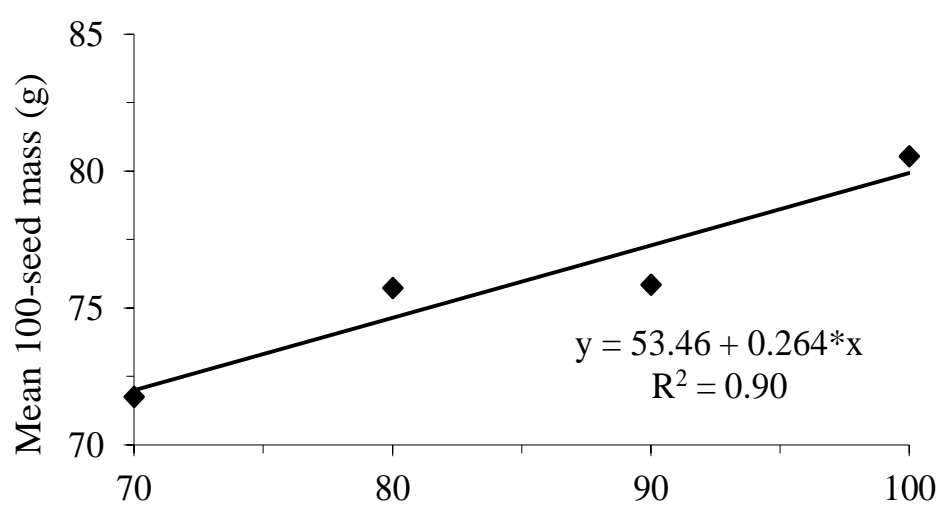

Available soil water $(\%)$

FIGURE 3. Mean 100-seed mass of the "BRS 188 Paraguaçu" cultivar as a function of available soil water level

The seed:fruit ratio was significantly affected by available water level in the soil $(\mathrm{p}<0.05)$ (Table 3$)$. The seed:fruit ratio of plants cultivated in soil with $100 \%$ available water was higher (0.709) than that of plants cultivated in soils with 90,80 , and $70 \%$ available water
(0.667, 0.643, and 0.633, respectively).

The seed: fruit ratio increased by $0.0025 \mathrm{~g}$ of seeds per $g$ of fruit produced with $1 \%$ increase in available water level in the soil (Figure 4).

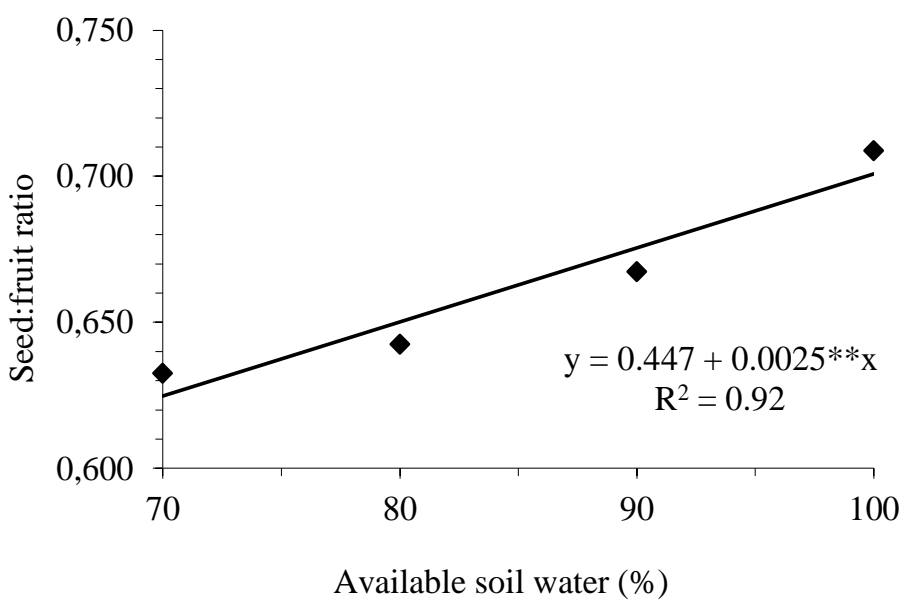

FIGURE 4. Seed:fruit ratio of the "BRS 188 Paraguaçu" cultivar as a function of available soil water level

According to Severino et al. (2005), castor bean peeling or improvement is one of the most important technological production process steps for this oilseed crop, mainly for indehiscent cultivars in which the fruit does not open easily and seed removal becomes very difficult; therefore, knowledge of this parameter is essential for a simplified estimation of castor bean productivity.

\section{Seed oil content}

Soil organic matter did not significantly affect seed oil content; however, available water level in the soil significantly affected seed oil content $(\mathrm{p}<0.05)$ (Table 4). 
TABLE 4. Summary of ANOVA results for seed oil content of the "BRS 188 Paraguaçu" cultivar.

\begin{tabular}{|c|c|c|}
\hline \multirow{2}{*}{ Source of variation } & \multicolumn{2}{|r|}{ Mean square } \\
\hline & DF & Oil Content $(\%)$ \\
\hline Organic matter (OM) & 1 & $0.735^{\mathrm{ns}}$ \\
\hline Available water (AW) & 3 & $13.027 *$ \\
\hline $\mathrm{OM} \times \mathrm{AW}$ interaction & 3 & $0.655^{\mathrm{ns}}$ \\
\hline Blocks & 2 & $10.593^{\mathrm{ns}}$ \\
\hline Residue & 14 & 3.649 \\
\hline $\mathrm{CV} \%$ & & 3.87 \\
\hline \multicolumn{3}{|l|}{ Available water } \\
\hline Linear Pol. Reg. & & $32.86 * *$ \\
\hline Quadratic Pol. Reg. & & $6.00^{\mathrm{ns}}$ \\
\hline Cubic Pol. Reg. & & $0.21^{\mathrm{ns}}$ \\
\hline Deviation & & $0.00^{\mathrm{ns}}$ \\
\hline Residue & & 3.64 \\
\hline \multicolumn{3}{|l|}{$\mathrm{OM}$} \\
\hline $5 \mathrm{~g} \cdot \mathrm{kg}^{-1}$ & & $49.19^{\mathrm{a}}$ \\
\hline $25 \mathrm{~g} \cdot \mathrm{kg}^{-1}$ & & $49.54^{\mathrm{a}}$ \\
\hline MSD & & 1.67 \\
\hline
\end{tabular}

$\mathrm{DF}$, degree of freedom; CV, coefficient of variation; MSD, minimum significant difference; Significant at $0.05(*)$ and $0.01(* *)$ probability; ${ }^{(n s)}$ not significant; means followed by the same letter in a column are not significantly different $(p>0.05)$.

Seed oil content showed a linear trend of increase (by $0.1 \%$ ) with per unit increase in available soil water level (Figure 5).

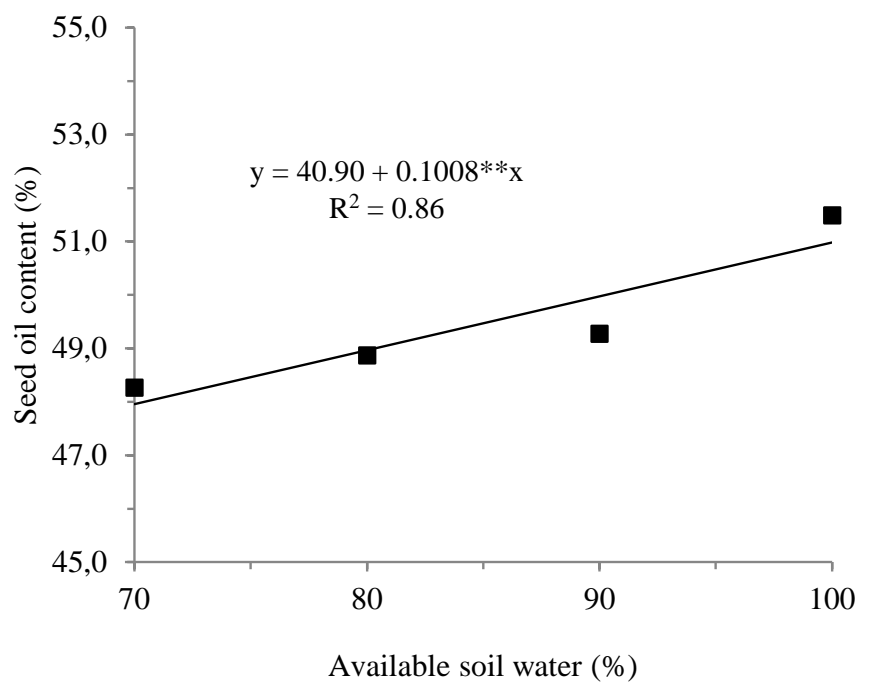

FIGURE 5. Seed oil content of the "BRS 188 Paraguaçu" cultivar as a function of available water level in the soil

Decreased available water in the soil, even occurring intermittently as a function of irrigation, reduced seed oil content. Mean seed oil content of plants cultivated in soil with $100 \%$ available water was $51.58 \%$, whereas that of plants cultivated in soil with 90,80 , and $70 \%$ available water were $49.27,48.86$, and $48.26 \%$, respectively.

Barros Júnior (2007) reported that water stress reduced seed oil content in plants cultivated in soil with $60 \%$ available water, which produced low-quality seeds; similarly, seed oil content reduced by over $53 \%$ in plants cultivated in soil with $80 \%$ available water compared with plants cultivated in soil maintained at the field capacity (100\% available water). In the castor bean hybrid "HD 912," Laureti (2002) reported a reduction in seed oil content of up to $50.70 \%$ when irrigated with progressive water blade reductions proportional to 75,50 , and $25 \%$ of crop evapotranspiration. Silva et al. (2007) obtained a seed oil content of $49.4 \%$ by varying nitrogenated fertilization levels and unrestricted soil water content.

\section{CONCLUSIONS}

Available soil water level positively and significantly affected castor bean productivity, both quantitatively and qualitatively. In the absence of water stress, castor bean trees are more efficient in converting water into plant mass, providing higher productivity.

Addition of organic matter to the soil significantly increased productivity of the tested castor bean cultivar, although it did not affect fruit and seed masses or seed oil content.

Available soil water level significantly increased fruit yield and seed oil content of the tested castor bean cultivar. Thus, water supply that maintains available soil water level below the field capacity in the root zone of plants will reduce fruit yield and seed oil content. 


\section{REFERENCES}

Azevedo DMP de, Beltrão NE de M (2007) O agronegócio da mamona no Brasil. Campina Grande, Embrapa Algodão, 2 ed. rev. e ampl. 504 p.

Barros Júnior G (2007) Efeito do conteúdo de água do solo, monitorado com TDR, sobre desenvolvimento e produção de duas cultivares de mamona. Tese Doutorado, Campina Grande, Universidade Federal de Campina Grande.

Barros Júnior G, Guerra HOC, Cavalcanti MLF, Lacerda RD de (2008) Consumo de água e eficiência do uso para duas cultivares de mamona submetidas a estresse hídrico. Revista Brasileira de Engenharia Agrícola e Ambiental 12(4):350-355.

Bayer C, Mielniczuk J (2008) Dinâmica e função da matéria orgânica. In: Satos GA, Silva LS, Canellas LP, e Camargo FAO (eds). Fundamentos da matéria orgânica de solo. Porto Alegre, Metrópole. 2 ed. rev. ampl.

Bernardo S, Soares AA, Mantovani EC (2008) Manual de Irrigação. Viçosa, UFV, 8 ed. 625p.

Carvalho BCL (2005) Manual do cultivo da mamona. Salvador, EBDA. 65p.

Curi S, Campelo Júnior JH (2004) Evapotranspiração e coeficientes de cultura da mamoneira (Ricinus communis L.), em Santo Antônio do Leverger, MT. In: Congresso Brasileiro de Mamona. Campina Grande, Embrapa Algodão, Anais... CD-ROM.

Diniz Neto MA, Tavora FJAF, Crisóstomo LA, Diniz BLMT (2009) Adubação NPK e épocas de plantio para mamoneira. I - Componentes da produção e produtividade. Revista Ciência Agronômica 40(4):578-587.

Ferreira PV (2000) Estatística aplicada a agronomia. Maceio, EDUFAL, 3 ed. 422p.

Freitas CAS de, Bezerra FML, Silva AR da, Filho JVP, Feitosa DRC (2010) Comportamento de cultivares de mamona em níveis de irrigação por gotejamento em Pentecoste, CE. Revista Brasileira de Engenharia Agrícola e Ambiental 14(10):1059-1066.

Gondim TMS de, Nobrega MB de M, Severino LS, Vasconcelos RA de (2004) Adensamento de mamoneira sob irrigação em Barbalha. CE. In: Congresso Brasileiro de Mamona. Campina Grande, Embrapa Algodão, Anais... CD-ROM.
Koutroubas SD, Papakosta DK, Doitsinis A (2000) Water requirements for Castor Oil crop (Ricinus communis L.) in a Mediterranean climate. Journal of Agronomy and Crop Science 184(1):33-41.

Lacerda RD de, Guerra HOC, Barros Junior G (2009) Influência do déficit hídrico e da matéria orgânica do solo no crescimento e desenvolvimento da mamoneira BRS 188 - Paraguaçu. Revista Brasileira de Ciências Agrárias 4(4):440-447.

Laureti D (2002) Fabbisogni idrici del ricino (Ricinus communis L.) mediante l'impiego di coefficienti colturali e de deficit idrico. Rivista Quadrimestrale 165.

Maccarthy P (2001) The Principles of humic substances. Soil Science 166(11):739-751.

Medici LO, Azevedo RA, Canelas LP, Machado AT, Pimentel C (2007) Stomatal conductance of maize under water and nitrogen deficits. Pesquisa Agropecuária Brasileira 42(4):599-601.

Rodrigues WN, Nicoline HO, Martins LD, Tomaz MA, do Amaral JFT (2010) Acúmulo de biomassa pela mamoneira submetida a diferentes adubações e aplicação de escória de siderurgia. Revista Verde de Agroecologia e

Desenvolvimento Sustentável 5(5):33-39.

Sampaio EVSB, Salcedo IH (1997) Diretrizes para o manejo sustentável dos solos brasileiros: Região semiárida. In: Simpósio Diretrizes para o Manejo Sustentável dos Solos Brasileiros. In: Congresso Brasileiro de Ciência do Solo. Rio de Janeiro, SBCS, Anais... CD-ROM.

Sausen TL, Rosa LMG (2010) Crescimento e limitações à assimilação de carbono em Ricinus communis (Euphorbiaceae) sob condições de estresse hídrico do solo. Acta Botanica Brasilica 24(3):648-654.

Severino LS, Morais CR, DE A, de Gondim TMS, Cardoso GD, dos Santos JW (2005) Fatores de conversão do peso de cachos e frutos para peso de sementes de mamona. Campina Grande, Embrapa Algodão, 14p (Documentos, 56).

Silva TR, Leite VE, Silva AR, Viana LH (2007) Adubação nitrogenada em cobertura na cultura da mamona em plantio direto. Pesquisa agropecuária brasileira 42(9):1357-1359.

Souza A dos S, Tavora FJAF, Pitombeira JB, Bezerra FML (2007) Épocas de plantio e manejo da irrigação para a mamoneira. II Crescimento e produtividade. Revista Ciência Agronômica 38(4):422-429. 